\title{
(SOC)REALISMS IN PRACTICE: RE-READING THE SOVIET EXPERIENCE IN THE 1930s
}

\section{A B S T R A C T}

The discourse on realism in contemporary architectural debate seems to circumvent the complexity of the historical roots of this phenomenon in the twentieth century architecture and, in particular, the discourse on socialist realism: a source of many perspectives gravitating around the idea of realism in postwar period and constituting a significant moment in the theoretical debate and design practice between the thirties and the fifties, until the death of Stalin.

The aim of this article is to propose an articulated reflection on the experience of socrealism, explored in its "formative" years, in the crucial phase of its elaboration. Far from being the result of a rigid, top-down theoretical determination, realism was defined in a pragmatic way, on many worksites of design practice and theory. The eclecticism and plurality of its expressions, gravitating around the idea of critical assimilation of history, explains the developments of the socrealism between war and post-war in The USSR and in eastern European countries and finds its clearest statement in the Moscow metro. 
Many of the discourses on realism in contemporary architectural debate such as those recently launched in Italy - seem to elide (at least part of) the complexity of the historical roots of this phenomenon in the twentieth century architecture.

In particular, this simplification applies to the problem of socialist realism that represented a significant moment in the theoretical debate and design practice from the thirties up to the fifties, and in "Western" countries (in Italy) has been a source of many paths gravitating around the idea of realism during the postwar period.

There are many reasons for this neglect of attention to this phenomenon.

It seems sufficient to mention the dissociation between theoretical developments and historiographical research, the embarrassment that socialist realism - for obvious political reasons - aroused in the years in which a new generation of Italian architects - close to the Communist Party - were consolidating academic and professional positions. ${ }^{1}$ When Manfredo Tafuri, exposed his criticism of realism, the knowledge about socrealism was very limited. Even in the socialist countries, including the USSR, a vision of censorship prevailed, as the realism was inextricably linked to Stalinist era. Young Soviet scholars - among others Selim O. Khan Magomedov and Vigdarija Khazanova ${ }^{2}$ - were engaged in the rediscovery of the Soviet avant-garde.

The result has been the total exclusion from the dominant narratives of the contemporary architecture; an exclusion that continues up to now, with very timid exceptions.

Moving from these premises, it seems interesting to reconsider an experience that decades of historiographical research allows us to penetrate and understand in all its complexity (and ambiguity) between technics and ideology, between innovative research and historicist formalism. As has been claimed many times even by the authoritative Western historians, (soc)realism in architecture and urban design was anything but an indefinite phenomenon. Looking at realism - considered not as a dogma but as a process - during its formative years, say 1930s, we can identify key-aspects that define a framework of organic values and treats alternative to those inspiring a large part of the European architectural experience after the World War Two. 
DOM NARKOMFIN VS DOM NA MOKOVOJ.

TOWARDS THE “CULTURE TWO"

Two buildings in Moscow provide an eloquent example of the change in climate that was to quickly overtake Soviet architecture during the nation's forced industrialisation, paving the way towards realism ${ }^{3}$. These are the Narkomfin ${ }^{4}$ complex and another residential building designed by Ivan Žoltovskij on Mokhovaya Street ${ }^{5}$, close to the Kremlin.

Conceived by architect Moisej Ginzburg (with Ignati Milinis and the engineer Sergej Prokhorov), the Dom NKF, a crystalline transcription of constructivist thought that revolved around OSA, was erected between 1928 and 1930. The magazine "SA-Sovremennaya Arkhitektura" presented the building in the typical rhetoric frame of the early Five Year Plan, dominated by calls for collectivism, standardization, production and a 'machine'-driven culture ${ }^{7}$. Although destined for an élite - that of the Commissariat of the People of Finance - it strove to prefigure and accompany its inhabitants towards a new collectivist way of life by offering an alternative, viable living standard for the masses as well as a solution to the increasingly drastic cohabitation then dominant in Moscow and other Soviet cities. For this reason the designers themselves termed this building perekhodnyj dom, "transitory". A transitory building towards a new byt (way of life), the Dom Narkomfina project was conceived as a criticism of the conventional solutions inspired by the garden city vision and "traditional" residential blocks, declaiming instead one of the most radical visions of organised Socialist housing schemes to break onto the whirlwind scenario of the Soviet Union's 1920s worksite ${ }^{8}$. The lack of official directives, together with the ongoing discussion concerning plans for

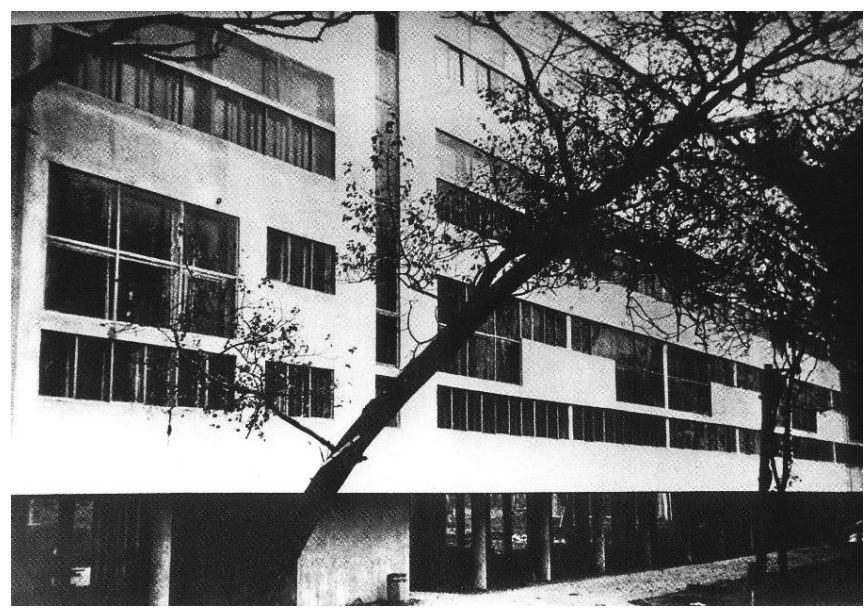

Figure 1. Moisej Ginzburg (with Ignati Milinis and the engineer Sergej Prokhorov), Dom NKF (Dom Narkomata Finansov), 1928-1930 
Moscow and other Soviet cities - as well as the existence of timidly articulated commissions with the NEP (Novaja Ekonomičeskaja Politika / New Economic Policy) and the proliferation of independent avant-garde associations and groups that were permitted and favoured into the early 1930s - legitimised all kinds of experimentation and favoured contact with western European modernism, which for a while looked as if it were about to triumph even in the Soviet Union, albeit in a very original form ${ }^{9}$. Both intellectual exchange and direct contact with leading contemporary architects and technicians in the West was still easy in the Soviet Union at the time, given that with the NEP the nation had once more opened up to trade as well as to economic and intellectual exchange ${ }^{10}$. Between 1928 and 1930 Le Corbusier made three trips to Moscow, where he took part in and won the design competition for the new central cooperatives headquarters (Centrosojuz). During those trips he did not fail to visit the Dom Narkomfina ${ }^{11}$ building site.

All this took place before the historic $\mathrm{KPb}$ (Communist Party) directive issued in June 1931, which laid down precise criteria for the reconstruction of the urban areas and banned radical ideas concerning the planned expansion of existing cities that had held such sway until then. That same year also marked the beginning of the fight against egalitarianism as a means for containing the economic and social upheaval generated by sudden industrialisation and collectivisation: another crucial step toward realism.

Following the 1930 campaign launched against the more radical fringes of architectural research catalysed by the personality of Ivan Leonidov (the so-called leonidovščina ${ }^{12}$ ), these measures ${ }^{13}$ were soon backed by a series of directives,

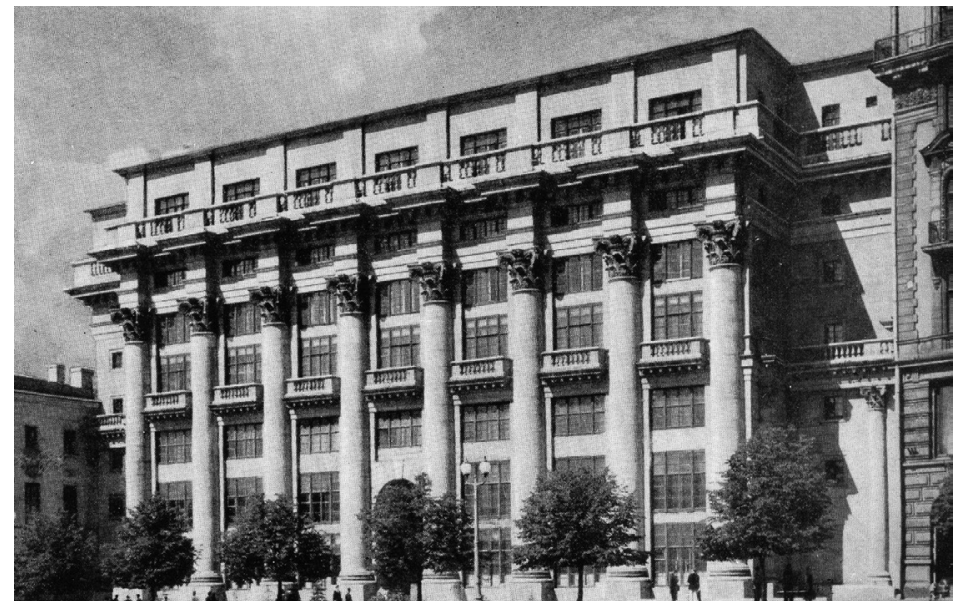

Figure 2. Ivan Žoltovskij, Dom na Mochovoj, 1934 
introduced first in Moscow and subsequently across the country, that defined the necessary characteristics required of housing to be in line with the regime's new economic, social and cultural policy. From the residential sphere, the same directives spread to all sectors in architecture. Overcoming the flat anonymity uravnilovka - of modern architectural lines in favour of more expressive forms derived from critical references to historical repertoire, as well as a "synthesis of the arts" capable of imbuing each single building with its own 'voice' to the masses, became of cardinal importance in the design and construction of new Soviet cities, as in the renovation of the existing ones. Contrary to the avantgarde currents of the 1920s, the various quarters of Soviet cities (kvartaly) were to be denoted by their functional or hierarchical symbology.

Designed and built as these events were unfolding, between 1932 and 1934, the severe Palladian references of the "house on the Mokhovaja" by Ivan Žoltovskij ${ }^{14}$ - a connoisseur of the Italian Renaissance and an established master prior to the Revolution - stood as a provocation to the aesthetics of the avantgarde that had been all the rage until shortly before but that were rapidly losing consensus amidst the changing scenario. The Dom na Mokhovoj's erudite revisitation and re-elaboration of the Loggia del Capitanio in Vicenza - in line with the most rigorous Russian Classicism developed in St Petersburg in the 1910s (such as the Markov residential building by Vladimir Ščuko ${ }^{15}$ ) - with its columns masterfully executed in the giant composite order punctuated by large vertical windows, was a statement to the vitality of Soviet architecture and its ability to respond to the unprecedented tasks required of it. Set apart from the neighbouring buildings by two lateral sections set in from the other facades, as if to underline its exemplary character, Ivan Žoltovskij's work provided a
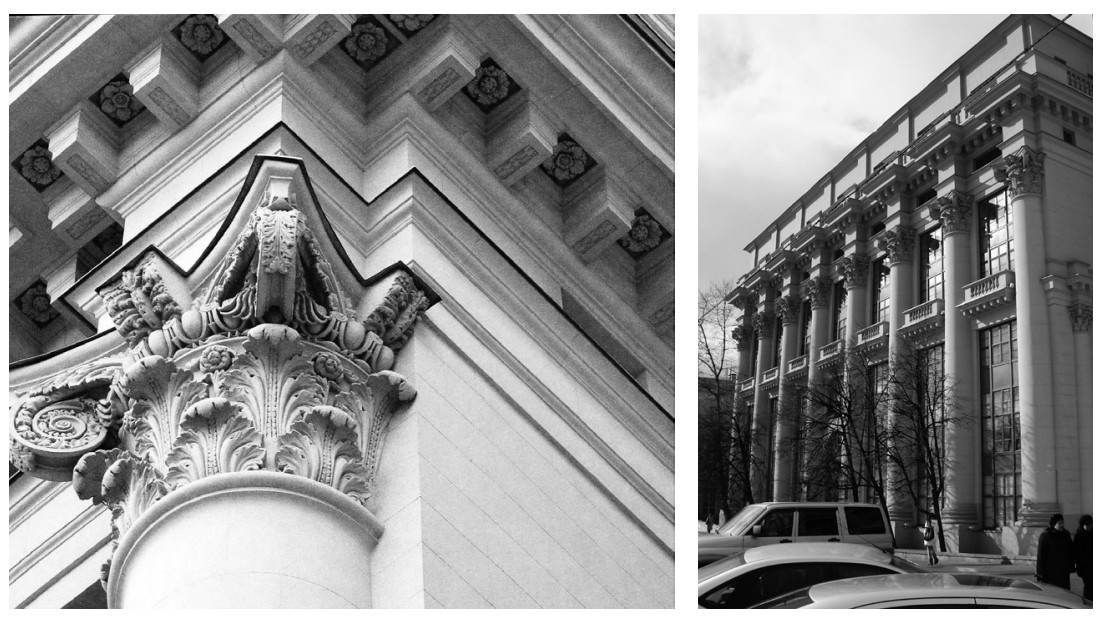

Figure 3-4. Ivan Žoltovskij, Dom na Mochovoj, Detail of Palladian order and main facade, 1934 
supreme lesson in execution. It also stood as a persuasive interpretation of what housing for the élite - the so-called ITR houses that were to represent almost all the housing projects in the following years up until the Kruščev revolution - and more in general what a building that aspired to speak the language of monumentality, could be. Inaugurated at the height of the debate on design theory and the legislation that redefined the orientation of the professional bodies $^{16}$ in architecture and other intellectual spheres affected by the April $23^{\text {rd }}$ $1932^{17}$ deliberation, Žoltovskij's building unleashed considerable controversy and came to epitomise the dispute. Some even branded it as the "nail" in the coffin of Constructivism.

Many still identify in this building - and even more so in the final project for the Palace of the Soviets ${ }^{18}$ (by B. Iofan, V. Ščuko, V. Gel'frejkh), the imposing ziggurat edifice surmounted by a colossal statue of Lenin - as marking the turning point towards a traditionalist revival of classicism in architecture that, through its monolithic and all-pervasive tone imposed on a political level ${ }^{19}$, would have annihilated even the most fertile creative strains that had emerged in the decade immediately after the Revolution.

Although such an interpretative approach does cover some crucial points of this period and it is undeniable that the burgeoning Stalinist decision-making system did play a decisive role, it must be noted that events were somewhat more complex and contradictory.

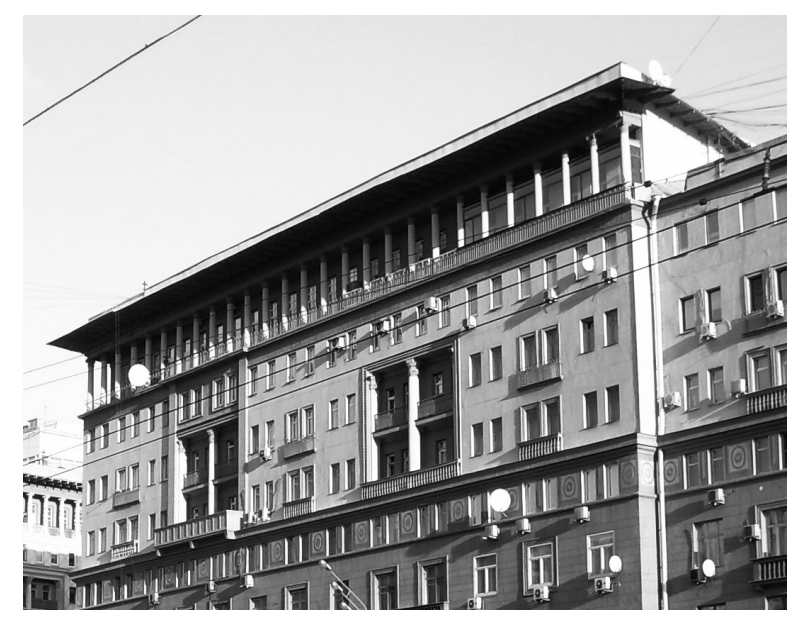

Figure 5. I. Vajnštejn, Residential building for technical elites, Moscow, 1932-1935 


\section{REALISM/REALISMS}

The idea of bureaucratically conditioned events driven by a precise and clearly identifiable stylistic polarisation no longer holds true. And neither is it correct to imagine a process unleashed unidirectionally at the highest political levels and quickly and passively declined into a uniformity of design. Given that - as indicated earlier - the 1930s saw a radical turning point, the image of a design culture as a crystallised product of an ideology stemming from a doctrine and a cultural normalisation is equally untrue. The period is effectively summed by Vladimir Paperny in a work that is still seminal today, when he termed "Culture two ${ }^{20 "}$ " an architecture and culture that carried with it heteromorphous values rather than the advanced artistic and intellectual narrative - not exclusive but largely dominant - of the 1920s.

In short, the evolution of Soviet architecture and urban planning in the Thirties and the Forties depended neither from the application of preconceived academic formulae nor from a univocally delineated ${ }^{21}$ relation between policies and power.

Despite the strong influence exerted by political events and decisions, the architectural climate under Stalin must be read also as a dense cultural project animated by extraordinary intellectual figures, among whom was Aleksander Gabričevskij22 who subsequently fell victim to persecution. This cultural atmosphere reverberated tangibly on the pages of periodicals such as "Architektura SSSR", "Akademija Architektury", “Architektura za rubežon"23 into the mid-thirties. Driven by research as well as a deep-rooted desire for
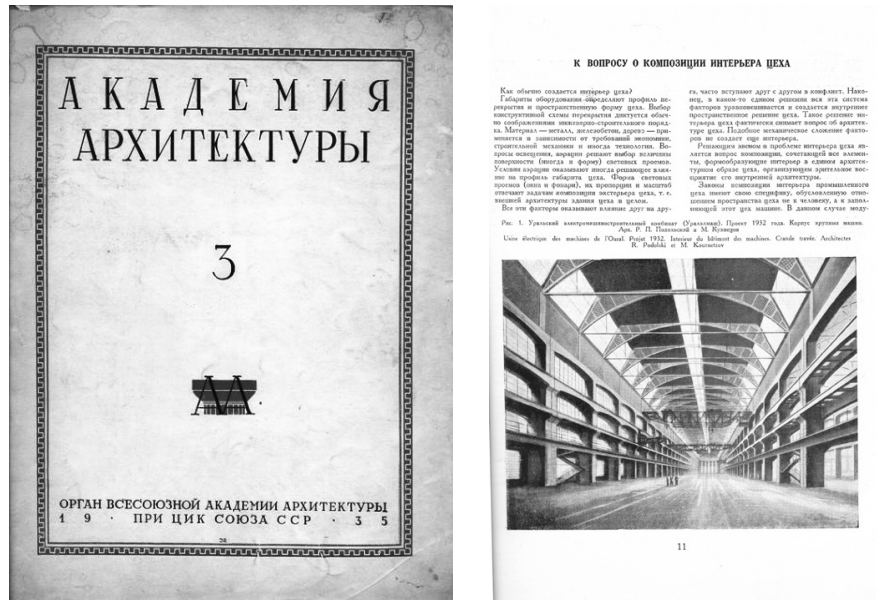

Figure 6-7. Akademija Architektury, 1935, N 3, Jurnal of Soviet Academy of Architecture

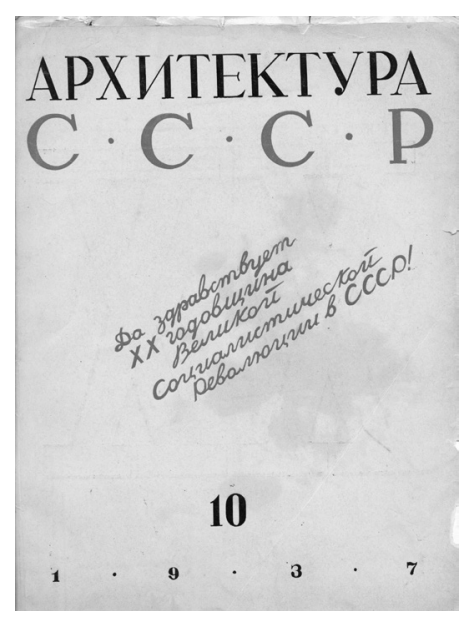

Figure 8. Architektura SSSR, 1937, $\mathrm{N}^{\circ}$ 10, Jurnal of the Union of Soviet Architects 
renewal in education ${ }^{24}$, schools and building sites, there was active discussion both in specialised institutions as well as in cross-generation debates among architects, be they in central or peripheral parts of the Soviet Union. Clearly Realism, in practice, was a phenomenon that suffered at the hands of the autocratic evolution of the system and the repressive climate that manifested itself in the 1930s, engulfing also the architectural culture ${ }^{25}$. Nonetheless, it was a multi-faceted phenomenon with strongly specific declinations in the nation's main urban centres (chiefly Moscow, Leningrad and Kiev) that passed through various stages of development before the War, during the conflict and in the late-Stalin period. Not one Realism, therefore, but many different 'Realisms', in the same way that - according to Lazar Kaganovič, one of the highest-ranking administrators in the 1930s - many were the facets of Stalin and Stalinism.

Initially a move against the uniformity of the Modernist aesthetic, which was impoverished by the low level of technology widespread in the Soviet Union at the time, Realism developed in parallel and in multiple sectors through a lengthy period of research and painstaking transformation. Among these aspects was the affirmation of the concept of compact city and the continuation between historic city and existing city, against the tabula rasa ideology of CIAM's discourse on urbanism.

There was also a radical reorganisation of the professional system through the creation of state architectural studios (arkhitekturnye masterskie) placed in competition against one another and under the direction of the country's leading designers. A critical assimilation and study of the Russian and international heritage was fostered over their denial, in search of architecture that communicated through a clearly perceivable character that would shape a society being edged towards a corporate re-hierarchisation by social policies ${ }^{26}$.

\section{TOWARDS A CRITICAL APPROPRIATION OF HISTORY}

The grandiose, rhetorical and celebratory features that distinguished the projects and buildings representative of the apparatus of the Soviet state dominated a variegated architectural panorama tied to conspicuous urban investments. That same panorama was in any case driven by diverse declinations and theoretical and practical needs that embraced both a number of different interpretations of 'klassicizm' (generally stemming from architects with a formative experience in St Petersburg such as Ivan Žoltovskij, Ivan Fomin, Aleksej Ščusev, Vladimir Ščuko, Vladimir Gel'frejikh, Lev Rudnev) and "post-Constructivist ${ }^{27}$ " strains. There were also elements that were not in line with the widespread 
historicisation gaining ground and which admitted scope for highly interesting technical and formal experimentations such as those on prefabrication pioneered shortly prior to the Second World War by Andrej Burov, which were to pave the way towards the great changes that were to take place in the 1950s. This variety of currents is testified to by a number of competition projects, such as those for the NKTP (the Heavy Industry Commissariat), as well as by completed buildings in Moscow and Leningrad such as Evgeni Levinson and V. Munc's Dom Promkooperacii.

Even intense at times, the confrontation in terms of theory and design between the different creative orientations - only superficially quelled by the banning of the various factions at an official level - continued to manifest itself blatantly and without reticence up until the second half of the 1930s. At the same time, the nation's design culture - particularly for industrial architecture - was open to solutions that were still close to rationalism. Some state commissions, such as that for the Narkomtjažprom presided by Sergo Ordžonikidze, on which many exponents of Constructivism worked, permitted and even favoured less orthodox solutions ${ }^{28}$.

The Moscow underground ${ }^{29}$, which in the 1930s ranked as the regime project par excellence, was designed and built as the new currents were developing and consolidating their terrain. Indicated as a benchmark experience in the Socialist Realism research, the work remains a highly eloquent example of those times. From Ivan Fomin's employment of the so-called "red Doric" simplified and modernised neoclassicism ${ }^{30}$ to Nikolaj Ladovskij' $\mathrm{s}^{31}$ work as one of the leading exponents of the Rationalist avant-garde, or the stations

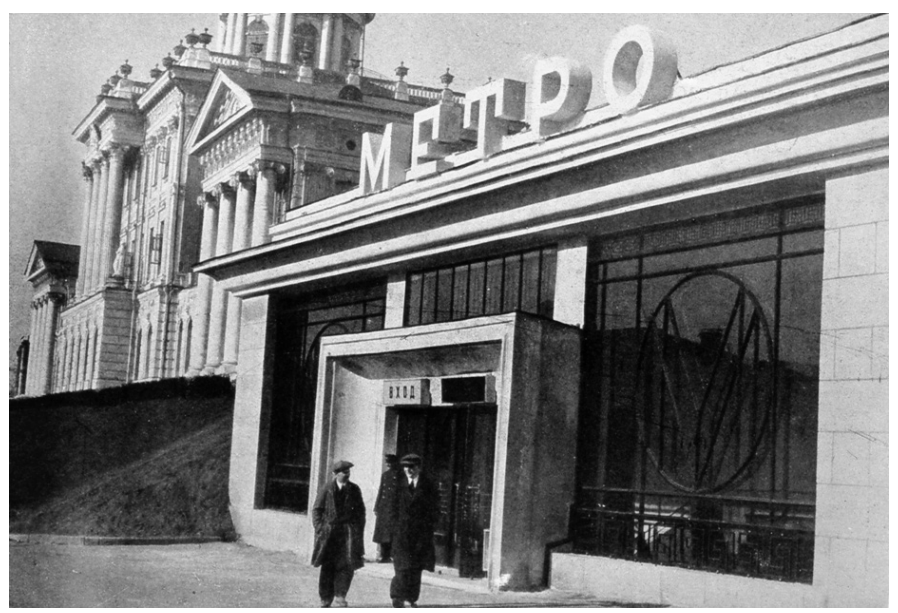

Figure 9. Entrance pavilion to the subway station of Ul. Kominterna (Lenin Librery), 1935 
designed by Nikolaj Kolli or Aleksej Duškin ${ }^{32}$, the stark difference in styles that make up the entire infrastructure - often combined in the same station through a strong juxtaposition between below surface spaces with pavilions at ground level in a sophisticated play between opposites - underline the breadth of formal strategies that were both admitted and encouraged, and which underpinned the same vision of Realism in architecture up until the second half of the 1930s. Many stations were dominated by references to the style that would later be termed Deco, which was unmistakably also the inspiration for the Soviet Union pavilions at the Universal Expositions of Paris and New York in 1937 and 1939, designed by the architect that more than any other can be considered the architect of the regime in those years: Boris Iofan. Born in Odessa, in the early years of the twentieth century Iofan studied in Rome and embarked on a career in Italy before returning to the Soviet Union.

Within the specific sphere of architecture, during the ten years that preceded the World War Two it is pluralism that best defines the evolution of Realism in the USSR, together with a hybridisation that marked the quest for a possible stylistic panorama guided by the principle of "critical" assimilation of history and contemporary trends within the framework of specific conditions dictated by local situations and tradition.

\section{THE URBAN DESIGN OF SOCIALIST REALISM}

The socrealizm design culture of the Stalin years in any case left a decisive mark on the appearance and structure of Soviet cities with its most basic urban developments - the kvartaly residential courtyard complexes, whose reconstruction or ex novo construction was launched before the War and either continued or redefined in the 1940s and mid-1950s. Moscow, whose redesign followed the historic concept of the city as the Third Rome ${ }^{33}$, was the reference case for the entire Soviet design. Judging by the indications contained in the Genplan Rekonstrukcii plan drawn up between 1932 and 1935 by Vladimir Semenov - the leading exponent of Russian urbanisation prior to the Revolution - a series of impressive public projects such as imposing residential superblocks, great city parks and the rearrangement of industrial areas began reshaping the image of the capital of the "proletarian State", exploiting and connecting a number of strategic districts within a context that was still heavily ruralised and rendered chaotic by uncontrolled development.

Rather than deny, erase or simply leave to its own "dissolution" - as advocated by many exponents of the avant-garde movements - Moscow's historical circular radius urban plan, this was given greater prominence and celebrated 


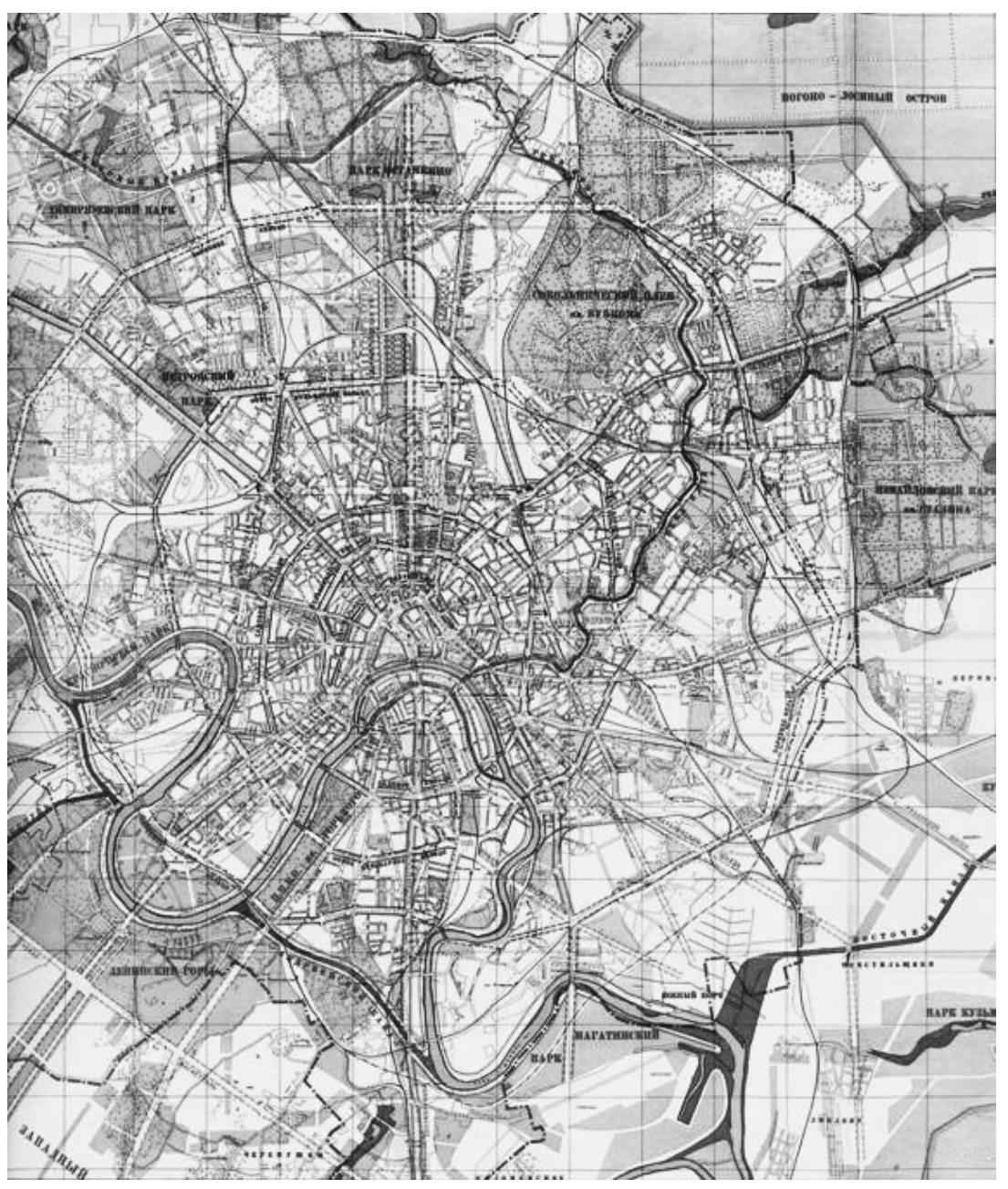


through a series of grandiose works concentrated around the Kremlin, along the river in the west of the city and on its main thoroughfares, which were broadened and realigned starting from the reconstruction of Tverskaya Street ${ }^{34}$.

Precisely because the confrontation between different trends was welcomed and stimulated in terms of research and debate, works completed in the early years of the decade prior to the War were characterised by the eclecticism open to many interpretations. In this period Soviet architecture was the synthesis of a painstaking theoretical re-elaboration process in specifically technical and disciplinary terms, carried forward on the dominating notes of "critical assimilation of history" and "synthesis of the arts". Designs were also measured against the specific nature of new works (the infrastructure, new representative and cultural buildings etc), which dictated new considerations, as well as the need to "organically" blend new constructions with an architectural context that in the heart of the city was strongly characterised by Modern (Art Nouveau), the important and irreplaceable legacy left to Moscow and elsewhere by the nation's late nineteenth and early twentieth century modernisation impulse ${ }^{35}$. Another decisive aspect that has already been mentioned was the drive for characterisation in buildings, which should be "readable", expressive and recognisable in both social and visual terms, and according to the type of building, within a general picture that was termed ansamblevaya zastrojka, or "building in coordinated design areas" - one of the cornerstone themes of urban composition that would be extended to countries within the Soviet sphere of influence after the War.

However, the War did shake ${ }^{36}$ these convictions considerably. Far from paralysing production and debate in design, particularly from 1943 to 1945 the War constituted a bounty of work for architects ${ }^{37}$, not only on a theoretical level. Discussion and debate - which was even heated at times, according to archive documents - in academic and research institutes questioned the directives of the previous period, calling for new priorities and a less rhetorical attitude based on a radical reorganisation of production that would have been favoured by technological exchange with the nation's allies. These considerations influenced a number of projects destined for the early stages of the reconstruction.

With the end of the conflict and the start of the Cold War, however, Soviet architecture unhesitatingly returned to its monumental style. The culminating - and in many respects paradigmatic - expression of this new phase of Socialist Realism, besides the improvements carried out on the nation's main water grid, 
are the vysotnye doma high-rise buildings that to this day, in a cityscape that has evolved considerably in the post-Communist market economy, stand out as one of the main visual landmarks of the Russian capital ${ }^{38}$. Having inherited the productive structure and design of the Palace of the Soviets, these skyscrapers were conceived as a means to confirm vertical development as the key element of the country's urban planning. Placed at strategic and privileged points in the Moscow area, they underlined the technical and constructive supremacy of the Soviet Union in opposition to "American" models and certainly constituted the finest example of architecture in the final stages of the Stalin socrealizm ${ }^{39}$ period. Each of these buildings was characterised by a specific reading of a theme taken from the Russian architectural tradition. As a whole they transcribed and sublimated on an urban scale the fusion between architecture and urban planning. The result was the affirmation of a triumphalist urban architecture derived from a unifying formal order and extended to the entire city, unlike the pre-War developments that had been limited to single districts.

The completion of vysotki, and the death of Stalin in 1953, marked a turning point between two different stages of post-War reconstruction and the redefinition of Realism, which continued to be the benchmark path - albeit with totally renewed contents - for the Soviet architectural culture during the de-Stalinisation era. Marsilio, 2000). Vasumi Roveri, Elisabetta. Aldo Rossi e l'architettura della città. Genesi e fortuna di un testo (Torino: Alemandi, 2010). 
Architektura SSSR, 6 (1934); I. V. Oščepkov, I. V. Žoltovskij, Proekty i postrojki (Moskva: Gos. izd. Lit. po strojtel'stvu i architekture, 1955).

Jean-Louis Cohen, “Avant-garde et revues d'architecture en Russie, 1917-1941," Revue de l'art, no. 89 (1990):29-38; J. L. Cohen, "La pjatiletka extraordinaire de Sovremennaja Arkhitektura / Neobyčnaja pjatiletka Sovremennoj Architektury / Ein ungewoehnlicher Funfjahrplan der Sovremennaja Architektura", attached to the reprint of the periodical (Ekaterinburg: Tatlin, 2010). Sheila Fitzpatrick (ed.), Cultural Revolution in Russia, 1928-1931 (Blooomington-London: Indiana University Press, 1978); Richard Stites, Revolutionary Dreams. Utopian Vision and Experimental Life in The Russia Revolution (New York, Oxford: Oxford University Press, 1989); Lynne Attwood, Gender and Housing in Soviet Russia. Private Life in a Public Space (Manchester: Manchester University Press, 2010).

Johannes Cramer and Anke Zalivako (eds.), Das Narkomfin-Kommunehaus in Moskau (19282012) (Petersberg: Michael Imhof Verlag, 2013).

Selim O. Magomedov Khan, Architektura Sovetskogo avangarda (Moscow: Strojizdat, 1996). Sheila Fitzpatrick, Alexander Rabinowitch and Richard Stites (eds), Russia in the Era of NEP. Explorations in Soviet Society and Culture (Bloomington, Indianapolis: Indiana University Press 1991).

Jean.-Louis Cohen, Le Corbusier et la mystique de l'URSS. Théories et projets pour Moscou 1928-1936. (Liège: Mardaga 1987); Žan-Lui Koen, Le Korbjuz'e i mistika SSSR. Teorii i proekty djja Moskvy 1928-1936. (Moskva: Art Volkonka, 2012).

A. Mordvinov, "Leonidovščina i ego vred," Isskustvo v massy, 12 (1930): 12-15; V. Lavrov, V. Popov, "Protiv nekritičeskogo otnošeniija k eksperimentam zapadnych architektorov," Stroitel'stvo Moskvy, 9 (1930): 8-12; De Magistris Alessandro and Korob'ina Irina (eds.), Ivan Leonidov 1902.1959 (Milan: Electa, 2009).

Alessandro De Magistris, "Culture architectural et projet urbain dans les annéea 30," Cahiers du monde russe et soviétique, Vol. XXXII, 4 (1991): 609-626; Alessandro De Magistris, La costuzione della città totalitaria (Milano: Città Studi, 1995); Alessandro De Magistris, "L'abitazione nella città sovietica tra la rivoluzione e gli anni trenta," Storia Urbana 101 (2002): 9-49; Ekaterina Azarova, L'appartement communitaire. L'histoire cacheé du logement soviétique (Paris: édit. Du Sextant, 2007).

Selim O. Khan Magomedov, Ivan žoltovskij (Moscow: Russkij Avangard, 2010).

William C. Brumfield, The Origins of Modernism in Russian Architecture (Berkeley: University of California Press, 1991).

Alessandro De Magistris. "Moscow in the 1930s: Realism and Bureaucratisation," Rassegna 75 (1998): 70-85; Igor' Kazus', Sovetskaja architektura 1920-ch godov. Organizacija i proektirovanie (Moskva: Progress-Tradicija, 2009).

Postanovlenie CK VKP (b) ot 23 aprelija 1932 goda "O perestrojke literaturnokhudožestvennykh organizacij " (The deliberation on the reconstruction of literary and artistic organisations)

Stroitel'stvo Moskvy 3 (1934); Catherine Cooke and Igor Kazus, Soviet Architectural Competitions 1920s-1930s (London: Phaidon, 1992).

Dmitrij Khmelnickij, Zodčij Stalin (Moskva: Novoe Literaturnoe Obozrenie, 2007); Alessandro De Magistris, "Per una storia del concorso del Palazzo dei Soviet 1931-1934," Casabella 838 (2014): 58-79.

Vladimir Paperny, Architecture in the Age of Stalin: Culture Two (London: Cambridge University Press, 2002).

Danilo Udovički Selb, "The evolution of Soviet Architectural Culture in the first decade of Stalin's 'Perestrojka' "“ Trondheim Studies on East European Cultures \& Societies 28 (2009). Aleksandr G. Gabričevskij, Sbornik Materialov (Moscow: Tretyakov Gallery, 1992); Aleksandr G. Gabričevskij, Teorija i istorija architektury (Kiev: Urtekst, 1993).

Alessandro De Magistris, 'Il dibattito architettonico degli anni '30-'50 nelle pagine di Architektura SSSR,“ Casabella 602 (1993): 46-53. 
Anna Opočinskaja, "Per una storia dell'Accademia di architettura pan sovietica," in URSS anni '30-'50, Alessandro De Magistris (ed.) (Milano: Mazzotta, 1997): 63-78; Moskovskij architekturnyj institut, 250 let moskovskoj architekturnoj skoly. Učebnye raboty i proekty (Moskva: A-Fond, 2000).

Hugh D. Hudson Jr, Blueprints and Blood: The Stalinization of Soviet Architecture, 1917-1937. (Princeton: Princeton Univ. Press, 1994).

Moshe Lewin, The Making of the Soviet System: Essays in the Social History of Interwar Russia (New York: Pantheon, 1985); Moshe Lewin, The Soviet Century (London: Verso, 2005); Vladimir Paperny, Architecture in the Age of Stalin: Culture Two (London: Cambridge University Press, 2002). Alessandro De Magistris and Irina Korob'ina (eds.), Ivan Leonidov. 1902-1959. (Milan: Electa, 2009). Alessandro De Magistris, "La metropolitana rossa,” Casabella 679 (2000): 8-29; J. Bouvard, Le Métro de Moscou, La construction d'un mythe soviétique (Paris: Ed du Séxtante, 2005); Aleksandr Dejneka, 1899-1969. An Avant-garde for the proletariat (Madrid: Fond. Juan March, 2012). Selim O. Khan Magomedov, Nikolaj Ladovskij (Architektura-S, Moscow, 2007). Nalalija Duškina and I. Čepkunova, Aleksej Nikolaevič Duškin. Architektura 1930-1950-kh godov (Moskva: MUAR, 2004).

Michail Agursky, The Third Rome. National Bolshevism in the USSR. (Boulder: Westview Press, 1987).

Timothy Colton, Moscow. Governing the Socialist metropolis. (Cambridge: Belknap Press of Harvard University Press, 1995); Alessandro De Magistris, La costruzione della città totalitaria (Milan: Città Studi, 1995); Harald Bodenschatz and Christiane Post (eds), Staedtebau im Shatten Stalins: die Internationale Suche nach der socialistischen Stadt in der Sowjetunion. 1929-1935. (Berlin: Verlagshaus Braun, 2003); Elisabeth Essaian, "Il piano generale di ricostruzione di Mosca del 1935 e la trasformazione del centro storico," Storia Urbana, XXVI, 101 (2002): 51-76. Elena Borisova and Grigorij Stergin, Russkij Modern (Moskva: Sovetskij Khudožnik, 1990); William C. Brumfield, The Origins of Modernism in Russian Architecture (Berkeley: Univesrity of California Press, 1991).

D. R. Stone (ed.), The Soviet Union at War. 1941-1945 (South Yorkshire: Pen\&Sword Books, 2010); Stephen Lovell, The Shadow of War. Russia and the USSR. 1941 to Present (West Sussex: Wiley-Blackwell, 2010). Iz istorii sovetskoj arkhitektury 1941.1945 gg. (Moscow: Nauka, 1978); Alessandro De Magistris, "URSS, l'altra ricostruzione," Rassegna, XV, no. 54 (1993): 76-83; Ju. L. Kosenkova, Sovetskij gorod 1940-ch-pervoj poloviny 1950-ch godov (Moscow: Librokom 2008). Andrej Ikonnikov, "Gli ‘edifici alti' di Mosca," in Alessandro De Magistris (ed.), URSS anni '30-'50, pp. 257-264.

Vjačeslav Oltarževkij, Stroitel'stvo vysotkich zdanij v Moskve (Moscow: Gos. Izdatel'stvo Literatury po stroitel'stvu i Architekture, 1953); N. Kulesov, A. Podznev, Vysotnye zdanija Moskvy (Moscow 1954). 
Åman, Anders. Architecture and Ideology in eastern Europe During the Stalin Era. An Aspect of Cold War History. Cambridge Mass: The Mit Press, 1992.

Bodenschatz, Harald and POST Christiane, (eds). Stäedtebau im Schatten Stalins: die Internationale Suche nach der sozialistischen Stadt in der Sowjetunion. 1929-1935. Berlin: Verlagshaus Braun, 2003.

Ciucci, Giorgio. Classicismo, Classicismi. Architettura Europa / America 1920-1940. Milano: Electa, 1995.

Colton, Timothy. Moscow. Governing the Socialist metropolis. Cambridge: Belknap Press of Harvard University Press, 1995.

Cohen, Jean-Louis (sous la dir). Les années 30. L'architecture et les arts de l'espace entre industrie et nostalgie. Paris: Éditions du patrimoine, 1997.

Cohen, Jean-Louis. Le Korbjuz'e i mistika SSSR. Teorii i proekty djja Moskvy 1928-1936. Moskva: Art-Volkhonka, 2012.

Dehaan, Heather D. Stalinist City Planning. Professionals, performance, and Power. Toronto: University of Toronto Press, 2013.

De Magistris, Alessandro. La costruzione della città totalitaria. Milano: Città Studi, 1995. De Magistris, Alessandro. Paesaggi dell'utopia staliniana. Milano: Mazzotta, 1997.

Golomštok, Igor. Totalitarnoe iskusstvo. Moskva: Galart, 1994.

Groys, Boris. Gesamtkunstwerk Stalin. München,Wien: Carl Hansen, 1988.

Hudson, Jr. Hugh D. Blueprints and Blood: The Stalinization of Soviet Architecture, 1917-1937. Princeton: Princeton Univ. Press, 1994.

Kazus', Igor'. Sovetskaja architektura 1920-ch godov. Organizacija i proektirovanie. Moskva: Progress-Tradicija, 2009.

Khan Magomedov, Selim O. Architektura Sovetskogo avangarda. Moskva: Strojizdat, 1996.

Kotkin, Stephen. Magnetic Mountain, Stalinism as Civilization. Berkeley-Los Angeles: University of California Press, 1995.

Magnago Lampugnani Vittorio (acura di). L'avventura delle idee nell'architettura 1750-1980. Milano: Electa, 1985.

Paperny, Vladimir. Kul'Tura 'Dva. 'Sovetskaia Arkhitektura. Moskva: Novoe Literaturnoe Obozrenie, 1996. (Transl.Architecture in the Age of Stalin: Culture Two. London: Cambridge University Press, 2002).

Rossi, Aldo. L'architettura della città, Padova: Marsilio, 1966.

Udovički Selb, Danilo. "The evolution of Soviet Architectural Culture in the first decade of Stalin's 'Perestrojka'.” Trondheim Studies on East European Cultures \& Societies 28, (2009).

Vasumi Roveri, Elisabetta. Aldo Rossi e L'architettura della città. Genesi e fortuna di un testo.

Torino: Allemandi, 2010. 


\section{ARHITEKTURA UTOPIJA REALIZAM: TEMATSKI OKVIR Ljiljana Blagojević}

Termin ili koncept realizma re-aktuelizovan je u skorašnjim teorijskim debatama od rasprava u filozifiji i estetici do onih u teoriji i praksi arhitekture. Počev od 2000. godine, arhitektonski diskurs se često bavi širokim spektrom srodnih pitanja koja proističu iz post-kritičkih rasprava o utopijanizmu i realizmu i mogućnosti jednog "utopijskog realizma", kako je to sugerirao Rajnhold Martin (2005). Rasprave o realizmu ponovo rezoniraju u arhitektonskoj teoriji kao odraz Manifesta novog realizma, filozofa Mauricija Ferarisa iz 2011 godine. Pitanja realizma naspram postmodernizma, "novog realizma" koji nastaje na pepelu post-modernizma, kritički i operativni pojmovi realizma i slično, postavljana su kako kroz prakse savremene arhitekture tako i kroz preispitivanje realizma i socijalističkog realizma u istoriji i teoriji arhitekture. Postavka tematskog okvira u ovom članku SAJ: Arhitektura Utopija Realizam ima za cilj da produbi tekuće rasprave o odnosima arhitekture sa realizmom i utopijom.

KLJUČNE REČI: ARHITEKTURA, UTOPIJA, REALIZAM, AUR MEĐUNARODNA NAUČNA KONFERENCIJA, UNIVERZITET U BEOGRADU - ARHITEKTONSKI FAKULTET

\section{UTOPIJA STVARNOSTI. REALIZMI U ARHITEKTURI IZMEĐU IDEOLOGIJE I FENOMENOLOGIJE Silvia Malcovati}

Predložen povodom Prvog Kongresa sovjetskih pisaca u Moskvi 1934 godine, pojam realizma u teorijskim raspravama o arhitekturi u ranim tridestim godinama dvadesetog veka, izgleda kao dvosmisleni pojam, koji se koleba između idealizma i ideologije, inovativnog istraživanja i istoricističkog formalizma. Neuspeh socijalističkog realizma i kriza njegove naglašene i monumenalističke arhitektonske slike, jasno pokazuju utopijski karakter realističkog "sna", ali isto tako, na neki način, njegovu maštovitu moć nastojanja da se izgradi bolji svet.

Pitanje realizma aktuelno je i posle Drugog svetskog rata. Posebno u Italiji realizmi se pretvaraju u alternative savremenoj paradigmi, ni manje ni više utopijski, već otvoreni prema novim postmodernističkim američkim idejama, kao i arhitekturi grupe "Tendenza".

U ovom radu predloženo je pregledno istraživanje realizama dvadesetog veka kao instrumenta koji odražava stanje u arhitekturi: nakon ekscesa postmodernog populizma, razočarenja "Architettura Razionale" i dijalektike rekonstrukcije - dekonstrukcije, izgleda da se ponovo pojavljuje u arhitekturi jedan novi bauk "Realizma" kao način reagovanja na trenutno arhitektonsko i urbano stanje.

KLJUČNE REČI: UTOPIJA, REALIZAM, ITALIJANSKA ARHITEKTURA POSLERATNOG PERIODA, “TENDENZA”, POSTMODERNIZAM, NOVI REALIZAM, ARHITEKTURA GRADA

\section{(SOC)REALIZMI U PRAKSI: PONOVNO ČITANJE SOVJETSKOG ISKUSTVA IZ TRIDESTIH GODINA PROŠLOG VEKA \\ Alessandro De Magistris}

Diskurs o realizmu u savremenoj arhitektonskoj raspravi izgleda da zaobilazi složenost istorijskih korena ove pojave u arhitekturi dvadesetog veka i, posebno, diskurs o socijalsitičkom realizmu: izvor mnogih perspektiva koje gravitiraju oko ideje realizma u posleratnom periodu i koje predstavljaju značajan momenat u teorijskoj raspravi i projektantskoj praksi između tridesetih i pedestih, sve do Staljinove smrti.

Cilj ovog članka je da predloži jedno artikulisano razmišljanje o iskustvu socrealizma, istraženog u njegovim "formativnim" godinama, u ključnoj fazi njegove razrade. Daleko od toga da je rezultat krutog, teoretskog određenja od vrha nadole, realizam je definisan na pragmatičan način, u većini radova projektanske prakse i teorije. Eklekticizam i pluralizam njegovih izražaja, koji gravitiraju oko ideje kritičke asimilacije istorije, objašnjava razvoj socrealizma između ratnog i posleratnog perioda u SSSR i istočno evropskim zemljama i nalazi svoj najjasniji iskaz u moskovskom metrou. 


\section{MANFREDO TAFURI I KRITIKA REALIZMA}

\section{Luka Skansi}

Jedna od glavnih tema istorijskog rada Manfreda Tafurija, bilo da je analizirao arhitekturu renesanse, iluminizma ili dvadesetog veka, ticala se odnosa između arhitektonskog stvaralaštva i stvarnosti. Ova tema takođe je premisa, odnosno uvodni teorijski okvir, za njegov istorijski i kritički diskurs "kritike realizma", koji je opisan u eseju Architettura e Realismo (Arhitektura i realizam), objavljenom 1985. godine. Ovaj esej predstavlja zaključne Tafurijeve opservacije italijanske posleratne arhitektonske kulture. Neorealizam postaje u njegovom eseju predmet prilično jedinstvene istorijske kontekstualizacije, predmet duboke kritike i, konačno, demistifikacije.

KLJUČNE REČI: ARHITEKTURA, REALIZAM, NEOREALIZAM, KRITIKA, POSLERATNA ITALIJA

\section{FRENK LOJD RAJT, EJN REND I HIPER-KAPITALISTIČKA UTOPIJA}

\section{Tijana Vujošević}

Ovaj rad predstavlja paralelno čitanje Frenk Lojd Rajtovog traktata Iščezavajući grad i Ejn Rendovog romana The Fountainhead. Autorka istražuje retoriku anti-urbanih utopija iz ere Depresije isnspirisanu mitom američkih pionira i osvajanjem granice. Ona identifikuje tri karakteristike Rajtovih i Rendovih anti-urbanih konstrukta: slavljenje muževnosti, poricanje političkog angažmana i anti-intelektualizam, sve to kombinovano u snu prvobitnog, idealnog kapitalizma. Koje su protivrečnosti i nedoslednosti svojstvene u građenju anti-urbane utopije? Ovo je pitanje na koje ovaj rad namerava da odgovori.

KLJUČNE REČI: MODERNIZAM, UTOPIJSKA FIKCIJA, ANTI-URBANIZAM, USONIA, THE FOUNTAINHEAD -

FAUNTEJNHED, IDEOLOGIJA, MUŠKOST, ANTI-INTELEKTUALIZAM

\section{MESTO [PROSTOR] NE-MESTO \\ Krunoslav Ivanišin}

Čak iako se nikada ne materijalizuju kao zgrade, arhitektonski projekti pripadaju stvarnom svetu. Odvojeno od stvarnog prisustva, ali bez lišavanja merljivih prostornih osobina, ovi skupovi tehničkih crteža u srazmeri, opisa i proračuna objašnjavaju buduću fizičku relanost u pogledu prostora, materijalnosti i forme, sa ciljem stvaranja sveta bar malo boljeg nego što je onaj iz koga potiču. Topografski izazovno, divno mesto pored mora; neko specifično gusto urbano okruženje; intrigantan način razmišljanja : neposredni kontekst prethodi i prati stvarnu izgradnju arhitektonskog dela. To je očigledna činjenica sama po sebi koju istoricističke konceptualizacije i klasifikacije ne mogu da poreknu. UTOPIJSKI ili REALISTIČNI, arhitektonski projekti su po svojoj prirodi vezani za mesta. Samo mera njihovog mešanja i uplitanja sa tim mestima može da varira. U našem post-globalizovanom svetu, i utopijski i realistični kvaliteti se mogu naći u projektima koji su hiperrealistični prema neposrednom kontekstu i koji se kontekstima bave minimalno, samo u pogledu raspoređivanja opterećenja, prilagođavanja stvarnoj topografiji, ili klimatskoj zaštiti.

KLJUČNE REČI: MESTO, ARHITEKTA, PROJEKAT, MATERIJAL, [PROSTOR], KONTEKTS, ARHITEKTURA, NE- MESTO 